\title{
JARINGAN SOSIAL PETANI: UPAYA PETANI PEMULA DALAM MEMBANGUN JARINGAN SOSIAL UNTUK MENGAKSES SUMBERDAYA USAHATANI
}

\section{FARMERS SOCIAL NETWORKS: THE EFFORT OF BEGINNING FARMERS IN BUILDING SOCIAL NETWORKS TO ACCESS BUSINESS RESOURCES}

\author{
Gema Wibawa Mukti*, Rani Andriani Budi Kusumo \\ Program Studi Agribisnis, Fakultas Pertanian Universitas Padjadjaran \\ *E-mail: gema.wibawa@unpad.ac.id \\ (Diterima 12-11-2021; Disetujui 22-01-2022)
}

\begin{abstract}
ABSTRAK
Makalah ini bertujuan untuk mengeksplorasi bagaimana jaringan sosial menyediakan akses terhadap sumberdaya kepada petani pemula, memahami sejauh mana petani pemula dengan latar belakang pertanian dan non pertanian membangun jejaring usaha mereka. Metodologi penelitian adalah kualitatif, disesuaikan dengan tujuan penelitian yaitu untuk memahami cara berpikir petani pemula dalam berjejaring. Data dikumpulkan antara bulan Oktober 2020 - Juni 2021, melalui wawancara semi terstruktur dengan 30 petani pemula di Jawa Barat. Petani yang memiliki latar belakang pertanian berjumlah 15 orang, dan 15 orang adalah petani pemula yang tidak memiliki latar belakang pertanian. . Hasil penelitian menunjukkan bahwa ikatan kuat dan lemah memberikan kontribusinya masing-masing bagi petani pemula untuk mengakses sumberdaya. Petani pemula yang bukan berasal dari lingkungan pertanian berjuang lebih keras untuk membangun jejaring bisnis, memberikan pengorbanan yang lebih besar dalam mengakses sumberdaya yang mereka butuhkan. Petani pemula non pertanian mampu mengakses sumberdaya material yang biasanya didapatkan dari ikatan sosial yang kuat. Ternyata dengan usaha dan pengorbanan yang keras, mereka mampu mendapatkan sumberdaya dari ikatan sosial yang lemah. Pertanian adalah sektor yang senantiasa mengalami perubahan yang cepat, sehingga kedua kelompok petani pemula ini harus mampu bergerak dengan cepat, melintasi "batas" untuk mengakses sumberdaya dengan cara yang inovatif dari berbagai sumber yang ada.
\end{abstract}

Kata Kunci : Sumberdaya, Jaringan Sosial, Jaringan Bisnis Petani, Petani Pemula

\begin{abstract}
This paper aims to explore how social networks provide farmers with access to resources, understanding the extent to which farmers with agricultural and non-agricultural backgrounds build their business networks. The research methodology is qualitative. Data was collected between October 2020 - June 2021, through semi-structured interviews with 30 farmers in West Java. There are 15 farmers who have an agricultural background, and 15 of them are novice farmers who do not have an agricultural background. The results showed that strong and weak ties each contributed to novice farmers in accessing resources. Beginner farmers who are not from the agricultural environment struggle harder to build business networks, making greater sacrifices in accessing the resources they need. Farmers with non-agricultural backgrounds are able to access material resources which are usually obtained from strong social ties. With hard effort and sacrifice, they are able to get resources from weak social ties. Agriculture is a sector that is constantly undergoing rapid changes, so these two groups of farmers must be able to move quickly, across "borders" to access resources in innovative ways from various existing sources.
\end{abstract}

Keywords: Resources, Social Network, Farmer Business Network, Beginning Farmer 


\section{PENDAHULUAN}

Pertanian di Indonesia secara tradisional dicirikan dengan ikatan sosial yang kuat diantara para anggota yang terlibat di dalamnya. Ikatan sosial ini seringkali berlaku seumur hidup dan terbentuk dalam sebuah jaringan lokal yang kecil dan juga homogen. Henri Mendras menjelaskan bahwa petani yang merupakan bagian dari penduduk desa, adalah mereka yang mengetahui semua "orang lain" yang terdapat di wilayah desa tersebut (Mailfert, 2007). Hubungan sosial yang kuat diantara para petani tradisional telah menciptakan budaya guyub yang kuat, sebagai suatu ciri khas dalam pertanian di Indonesia (Wood et al., 2020). Perubahan-perubahan yang terjadi dalam sistem pertanian secara global, secara alami telah mengkonstruksi ulang ikatan-ikatan yang terjadi diantara para petani dan warga desa secara umum. Perubahan-perubahan yang terjadi telah mendorong terbentuknya hubungan sosial baru, sebuah ikatan sosial alternatif bagi mereka, sebuah ikatan sosial baru yang melibatkan pelaku pertanian dari luar (asing), model bisnis inovatif dan ruang lingkup bisnis yang lebih luas (Mailfert, 2007; Palmioli et al., 2020).

Implikasi dari perubahanperubahan tersebut adalah pentingnya keterampilan relasional untuk dimiliki oleh seorang petani, sehingga mereka dapat berinteraksi secara efektif dalam jaringan bisnis pertanian. Keterampilan ini menjadi penting untuk mendukung keberhasilan bisnis pertanian (Flora et al., 2001; McElwee \& Bosworth, 2010). Jaringan bisnis dan jejaring sosial menjadi aspek penting bagi setiap individu yang hendak memasuki bisnis pertanian. Petani saat ini tidak lagi menjadi pekerjaan yang ekslusif, selalu berasal dari keluarga petani, anak lakilaki atau berasal dari lingkungan pertanian. Petani pemula/petani muda saat ini berasal dari berbagai latar belakang, mencari kehidupan dalam bidang pertanian sebagai salah satu alternatif ekonomi di tengah sulitnya mencari pekerjaan atau menjalankan bisnis pada masa pandemi Covid 19.

Petani pemula mungkin belum memiliki keterampilan dasar bertani, selain itu juga mereka dianggap sebagai "orang asing" pada komunitas baru nya (Pyysiäinen et al., 2006). Tentunya hal tersebut menjadi tantangan tersendiri bagi petani pemula, dimana mereka harus mengembangkan keterampilan dasar bertani dan juga menjalin hubungan sosial dengan petani dan masyarakat sekitar. Petani pemula harus berjejaring, 
membentuk hubungan sosial dengan petani yang telah terlebih dahulu menjalankan bisnis pertanian (G McElwee \& Robson, 2005). Jaringan sosial secara hipotesis memainkan peran penting bagi petani pemula untuk memperoleh sumberdaya pertanian, informasi dan dukungan sosial bagi mereka dalam menjalankan bisnis pertanian.

Makalah ini bertujuan untuk mengeksplorasi bagaimana petani pemula/petani muda membangun jaringan bisnis pertanian dalam fase awal membangun bisnis, bagaimana mereka mendapatkan akses ke sumberdaya utama (key resources) dan mitra utama mereka dalam membangun bisnis (key partnership). Penelitian ini juga berusaha untuk memahami mekanisme jaringan seperti apa yang berperan dalam penyediaan sumberdaya bagi petani pemula, apakah terdapat perbedaan antara jaringan bisnis dan perilaku berjejaring dari petani pemula, terutama mereka yang bukan berasal dari latar belakang pertanian seperti halnya petani tradisional yang memiliki kultur bertani yang kuat. Penelitian ini berupaya untuk memahami jaringan bisnis pribadi petani pemula, tidak mengadopsi pendekatan "seluruh jaringan". Hal ini dilakukan karena hubungan sosial yang dilakukan oleh petani untuk memperoleh sumberdaya pada fase awal tidak meliputi seluruh jaringan sosial (Meixner et al., 2009), seperti misalnya lingkungan sosial atau kelompok tani.

Penelitian ini fokus pada jaringan pribadi petani pemula (start-up pertanian), yaitu orang-orang terdekat yang berada di sekitar petani pemula, yaitu mereka yang membantu secara langsung, bersedia untuk diajak diskusi tentang bisnis pertanian atau membantu ketika masalah muncul pada awal-awal fase membangun bisnis. Orang-orang terdekat ini lah yang merupakan jaringan pribadi dari petani pemula, yaitu orangorang yang langsung dapat diajak berdiskusi untuk menyelesaikan sebuah permasalahan yang muncul. Studi dilakukan di Jawa Barat, yaitu pada sentra-sentra agribisnis seperti Kabupaten Bandung, Kabupaten Garut dan Kabupaten Cianjur. Jawa Barat merupakan salah satu sentra pertanian yang memiliki peranan penting terhadap perekonomian di Indonesia (Novitasari, 2019). Keberadaan petani-petani pemula menjadi penting, yaitu sebagai aktor utama dalam menjaga agar sektor pertanian di Jawa Barat dapat tetap eksis dan berkembang. 
Pandemi Covid 19 telah mendorong sebagian generasi muda untuk menjadi petani, meskipun mereka tidak memiliki latar belakang pertanian. Kesulitan mencari pekerjaan dan menjalankan bisnis di sektor non pertanian membuat mereka "terpaksa" menggeluti pertanian. Tentunya fenomena ini menjadi salah satu pendorong bagi peneliti untuk melakukan penelitian ke dalam jaringan sosial pendatang baru profesi petani. Makalah ini dimulai dengan penjelasan mengenai petani pemula di Jawa Barat, diikuti dengan tinjauan literatur tentang jaringan sosial yang terkait dengan konteks startup pertanian. Selanjutnya adalah menyajikan metodologi dan hasil penelitian dari studi kualitatif jaringan sosial petani pemula yang dilakukan di Jawa Barat.

Tujuan penelitian ini diantaranya adalah: 1) Mengkaji bagaimana jaringan sosial menyediakan akses terhadap sumberdaya kepada petani pemula, 2) Memahami sejauh mana petani pemula dengan latar belakang pertanian dan non pertanian membangun jejaring usaha mereka. Penelitian ini mencoba untuk melihat bagaimana sebuah jaringan bisnis pertanian dapat berfungsi untuk menghasilkan sumberdaya. Proses memperoleh sumberdaya ini apakah melalui proses tertutup (Coleman, 1988), yang terjadi melalui sebuah ikatan yang kuat dan kepercayaan yang kuat antar aktor, atau melalui proses terbuka (Granovetter, 2005), yang terjadi melalui ikatan yang lemah, akses yang lebih terbuka terhadap sumberdaya, atau mungkin juga melalui kedua ikatan tersebut yang melengkapi satu sama lain.

\section{Petani Pemula di Jawa Barat: Merubah Diri Atau Merubah Kebijakan}

Seorang pengusaha harus mulai berinvestasi membangun jaringan bisnis sebagai modal penting dalam mengembangkan usahanya. Pierre Bourdieu mengatakan bahwa jaringan itu tidak diberikan, namun harus dibangun (Bourdieu, 1986). Pernyataan ini menjadi pengetahuan penting bagi calon pengusaha, termasuk mereka yang akan berkecimpung dalam bisnis pertanian. Jumlah petani kecil di Indonesia merupakan bagian terbesar dari penduduk miskin, meskipun keberadaannya masih menjadi kunci penting dalam pembangunan pertanian (Kementerian Pertanian RI, 2015). Pemerintah melalui Kementerian Pertanian telah mendorong regenerasi petani, menerapkan strategi kebijakan pembangunan pertanian yang 
lebih spesifik untuk mendorong generasi muda terjun dalam bisnis pertanian. Kementerian Pertanian pada tahun 2013 telah secara khusus menyusun kebijakan mengenai regenerasi petani, yang dituangkan dalam Peraturan Menteri Pertanian Nomor 07/Permentan/OT.140/1/2013 tentang Pedoman Pengembangan Generasi Muda Pertanian.

Pertanian merupakan sektor ekonomi yang memberikan kontribusi terbesar dalam menyerap tenaga kerja. Sebanyak $32 \%$ tenaga kerja muda terserap ke dalam sektor pertanian (Kementerian Pertanian, 2013). Meskipun demikian, generasi muda terutama di daerah perdesaan sudah merasa tidak tertarik untuk berkecimpung dalam dunia pertanian. Terdapat beberapa alasan mengapa generasi muda perdesaan tidak lagi tertarik untuk berwirausaha dalam bidang pertanian (White, 2012), diantaranya 1) Pendidikan di Indonesia yang belum menjadikan pertanian sebagai salah satu peluang bisnis yang menjanjikan, 2) Kebijakan pemerintah yang belum menyentuh pertanian skala kecil dan infrastruktur perdesaan, dan 3) Sulitnya akses petani muda terhadap lahan karena keterbatasan atau penguasaan lahan oleh korporasi besar, dan masih enggan nya petani tua untuk berbagi lahan bagi petani muda.

Petani pemula memiliki akses yang terbatas terhadap sumberdaya lahan, modal finansial dan teknologi, sehingga diperlukan modal sosial yang berasal dari lingkungan sosial. Dukungan pemangku kebijakan berupa regulasi dan dukungan politik terhadap pertanian dirasa masih kurang optimal, sehingga mengurangi peluang pelaku usaha pertanian (petani pemula dan petani muda) untuk meningkatkan kesejateraannya (Mudiarta, 2017). Pengembangan bisnis petani saat ini masih fokus pada peningkatan produksi, belum mampu mengoptimalkan potensi lokal yang terdapat di wilayah perdesaan. Potensi jaringan sosial yang begitu kuat di wilayah perdesaan saat ini seakan-akan memudar, sehingga mereka semakin tergerus oleh arus globalisasi.

Jaringan sosial di wilayah perdesaan merupakan modal sosial yang kuat dan telah menjadi perhatian beberapa pakar dalam beberapa dekade terakhir (Bourdieu, 1986; Dasgupta \& Serageldin, 2000; Dinda, 2014; Spigel, 2016). Modal sosial memiliki peranan yang besar dalam mengentaskan kemiskinan dan pengembangan ekonomi pada suatu wilayah (Grootaert, 1999). Makalah ini akan lebih menitikberatkan 
pada aspek modal sosial, terutama jaringan sosial (networking) yang dihubungkan dengan pengembangan petani pemula berbasis komunitas sosial. Kebijakan pemerintah untuk mendidik dan memperkuat generasi muda dengan pengetahuan mengenai manajemen bisnis merupakan sebuah langkah yang positif, namun apakah hal tersebut telah cukup? Petani pemula tentu memerlukan pengetahuan mengenai manajemen bisnis dalam bidang pertanian (Phillipson et al., 2004), namun mereka pun akan sangat memerlukan dukungan dari berbagai pihak dalam lingkungan usahanya (Heaney \& Israel, 2008; Mailfert, 2007).

Fenomena yang terjadi di sektor pertanian Jawa Barat pada masa pandemi covid 19 adalah banyak bermunculan petani pemula yang tidak berlatar belakang pertanian. Mereka tidak berasal dari wilayah perdesaan yang lebih familiar terhadap sektor pertanian, dan mendapatkan dukungan sosial yang cukup dari lingkungan sosial mereka (Baker, 2014). Pada tahun 2021, Pemerintah Provinsi Jawa Barat meluncurkan program petani milenial yang ditujukan bagi generasi muda yang ingin berwirausaha dalam bidang pertanian. Mereka yang mendaftar tidak seluruhnya memiliki latar belakang pertanian, belum memiliki kultur pertanian yang kuat dibandingkan dengan mereka yang memiliki latar belakang pertanian.

Generasi muda yang melihat peluang lain dalam bisnis pertanian mulai berpindah ke wilayah perdesaan. Kaum muda ini mencari tatanan sosial dan ekonomi yang ideal, dimana mereka merasa leluasa untuk menciptakan alternatif kehidupan bagi diri mereka sendiri, mengembangkan bisnis pertanian dan hidup sebagai petani. Kemudian bagaimana dengan penerimaan masyarakat tradisional perdesaan terhadap kedatangan "orang luar" di daerah mereka? Tentunya reaksi penduduk lokal sangat beragam, ada yang menerima dengan baik atas dasar kesamaan nasib, atau mungkin menolak karena menganggap mereka sebagai "pesaing" yang dapat mengancam bisnis pertanian di wilayah mereka sendiri. Kegagalan petani pemula ini dalam memulai bisnis seringkali disebabkan oleh kegagalan mereka dalam berintegrasi/berhubungan dengan masyarakat sosial di lingkungan baru mereka (Acheampong et al., 2017).

Penelitian ini mencoba untuk mengungkap pentingnya seorang petani pemula untuk memiliki kemampuan 
untuk berjejaring, membangun hubungan sosial yang positif dengan petani dan masyarakat dalam lingkungan sosial mereka. Aspek ini menjadi penting bagi mereka, tentunya selain kemampuan teknis bertani dan juga manajemen usahatani. Petani pemula ini tidak lagi bagian yang terpisahkan dalam komunitas masyarakat perdesaan, senantiasa mendorong diri mereka untuk mengintegrasikan diri ke dalam komunitas lokal, secara perlahan mendapatkan kepercayaan mereka dan akhirnya mereka diterima dengan baik dalam lingkungan pertanian secara baik. Kemampuan berjejaring seperti ini menjadi penting untuk dimiliki oleh seorang pemula, sehingga mereka akan mendapatkan dukungan sosial yang cukup untuk memulai usaha dan mendapatkan akses terhadap sumberdaya yang mereka perlukan untuk pengembangan usahanya (Semrau \& Werner, 2014).

\section{Kerangka Teoritis: Jaringan Sosial Dalam Bisnis Pertanian}

Literatur mengenai analisis jaringan sosial secara akademik terus berkembang, tidak hanya pada ilmu sosial, namun pada seluruh disiplin ilmu yang terkait dengan studi perdesaan dan sosial ekonomi pertanian. Seperti misalnya (Beggs et al.,
1996) menjelaskan perbedaan antara perdesaan dan perkotaan dengan menggunakan pendekatan jaringan sosial. Studi lainnya tentang jaringan inovasi, berusaha untuk membedakan jaringan vertikal - horizontal yang mempengaruhi jaringan aktor dan analisis rantai komoditas di wilayah perdesaan (Murdoch, 2000).

Aktor ekonomi dalam sebuah jaringan sosial pada prinsipnya bukan lah sebuah entitas yang terpisah dari konteks masyarakat secara umum, namun mereka juga tidak sepenuhnya mengikuti aturan sosial yang berlaku pada masyarakat (Granovetter, 2005). Beberapa literatur sebelumnya telah mempelajari jaringan informasi petani berdasarkan pengetahuan dan pengalaman mereka, namun tidak secara spesifik mempelajari perilaku petani pemula dalam mengakses jaringan informasi ini (Hassanein, 1999). Jaringan merupakan aspek penting bagi keberhasilan petani pemula untuk memulai bisnis mereka, meskipun beberapa studi yang ada belum secara spesifik fokus untuk mempelajari bagaimana petani pemula berjejaring.

Pendekatan teoritis dalam makalah ini melihat analisis jaringan sosial yang ditemukan pada literatur modal sosial dan kewirausahaan. Studi dalam modal sosial 
menjelaskan bagaimana seorang pelaku usaha memanfaatkan jaringan sosial untuk mengakses sumberdaya ekonomi yang mereka butuhkan. Perilaku ini merupakan investasi yang dilakukan oleh petani pemula untuk mencapai target bisnis yang diharapkan, dimana investasi ini berupa relasi sosial dan jaringan kolaborasi, baik itu di tingkat mikro, meso ataupun makro (Nee, 2005). Modal sosial dan kewirausahaan dalam makalah ini dapat diartikan sebagai jaringan sosial yang dapat diakses dan dimanfaatkan oleh para petani pemula (Mudiarta, 2017). Semakin baik posisi seorang petani pemula dalam suatu jaringan sosial, maka akan semakin baik pula peluang dia untuk dapat mengakses dan memanfaatkan sumberdaya yang dibutuhkan (Mudiarta, 2017).

Ketidaksetaraan posisi sosial dan ekonomi diantara individu akan menghambat seorang individu dalam mengakses berbagai sumber modal yang dibutuhkan. Kondisi ini yang seringkali membuat petani pemula atau petani muda menjadi terpinggirkan, sehingga mereka sulit mengembangkan usahanya secara optimal. Posisi sosial ekonomi yang setara mengacu pada hubungan dalam kelompok yang homogen (antar petani), hubungan dengan keluarga, teman dekat yang dapat memberikan manfaat emosional dan juga materi bagi petani pemula, namun seringkali dapat menghambat inovasi. Posisi sosial ekonomi yang tidak setara biasanya menghubungkan petani dengan kelompok yang berbeda secara sosial, geografis atau identitas dalam jaringan yang terbuka. Literatur kewirausahaan telah menjelaskan mengenai hubungan antara jaringan dan akses terhadap sumberdaya. Jaringan telah lama dianggap sebagai aspek penting dalam kesuksesan bisnis, terutama pada fase start-up atau pemula (Casson \& Giusta, 2007; Greve \& Salaff, 2003; Zimmer, 1986). Menurut literatur ini, para pengusaha pemula, termasuk di dalamnya petani sebagai bagian dari pelaku usaha, menggunakan jejaring mereka untuk mendapatkan sumberdaya yang mereka butuhkan, dengan biaya yang lebih rendah dibandingkan dengan yang lain.

Seorang petani yang memiliki jejaring yang lebih besar dan beragam, tentu akan mendapatkan lebih banyak dukungan dari mereka yang memiliki jaringan yang lebih kuat. Jejaring dengan orang-orang yang beragam dapat memperluas jangkauan ide yang dapat diakses oleh seorang pengusaha pemula (Witt, 2004). Ikatan yang terpercaya juga 
penting bagi seorang pengusaha pemula untuk memperoleh akses terhadap keuangan dan bantuan praktis untuk proses bisnis mereka (Jenssen, 2001; Jenssen \& Koenig, 2002). Penjelasan lain yang akan dipaparkan dalam makalah ini adalah perilaku petani pemula yang memiliki akses sumberdaya yang terbatas, akan berjuang lebih keras untuk mendapatkan sumberdaya yang dibutuhkan nya (Brüderl \& Preisendörfer, 1998; Kuntarič et al., 2012). Pada awal memulai bisnis, petani pemula dihadapkan dengan sebuah proses bisnis yang unik, menjalani sebuah bisnis dengan ketidakpastian dan risiko yang tinggi.

Petani pemula mulai menjajagi "medan" bisnis yang menantang, tergantung pada alam dan mungkin kondisi pasar yang tidak menentu. Menghadapi tantangan seperti ini tentunya akan membutuhkan ikatan yang kuat untuk memberikan dukungan dan dorongan emosional kepada para petani pemula ini. Mereka harus memiliki kemampuan untuk belajar secara cepat, menguasai keterampilan teknis pertanian dan juga memahami pasar secara cepat. Jejaring sosial, baik itu berupa ikatan yang kuat ataupun lemah akan diperlukan oleh petani pemula untuk mengakses informasi seputar bisnis pertanian, mengakses sumberdaya pertanian yang memang vital bagi keberlangsungan usaha mereka. Makalah ini akan fokus pada pembahasan mengenai jejaring petani pemula sebagai modal sosial dan juga pendekatan kewiirausahaan untuk menganalisis jaringan tersebut.

\section{METODE PENELITIAN}

Metodologi penelitian adalah kualitatif, disesuaikan dengan tujuan penelitian yaitu untuk memahami cara berpikir petani pemula dalam berjejaring. Data dikumpulkan antara bulan Oktober 2020 - Juni 2021, melalui wawancara semi terstruktur dengan 30 petani pemula di Jawa Barat. Petani yang memiliki latar belakang pertanian berjumlah 15 orang, dan 15 orang adalah petani pemula yang tidak memiliki latar belakang pertanian. Responden diambil secara purposive, untuk memastikan kami dapat melihat keragaman perspektif, pengalaman serta karakteristik sosial ekonomi yang optimal. Petani yang berlatar belakang pertanian, adalah petani hortikultura, dengan produk usaha yang beragam seperti sayuran daun, cabai, tomat dan buncis. Petani yang menjadi responden dalam penelitian ini adalah petani muda yang berusia antara 20-39 tahun. 
Wawancara semi terstruktur didukung oleh kuisioner yang berisi pertanyaan terkait dengan dukungan sumberdaya yang dibutuhkan oleh seorang petani pemula. Beberapa pertanyaan yang terdapat dalam kuisioner mencakup beberapa aspek, seperti misalnya 1) Dukungan materi seperti pinjaman modal, tanah, bibit dan lain sebagainya, 2) informasi dan pengetahuan mengenai aspek teknis dan non teknis pertanian, dan 3) dukungan dan doronga emosional. Apabila digambarkan, maka proses wawancara akan melalui proses sebagai berikut:

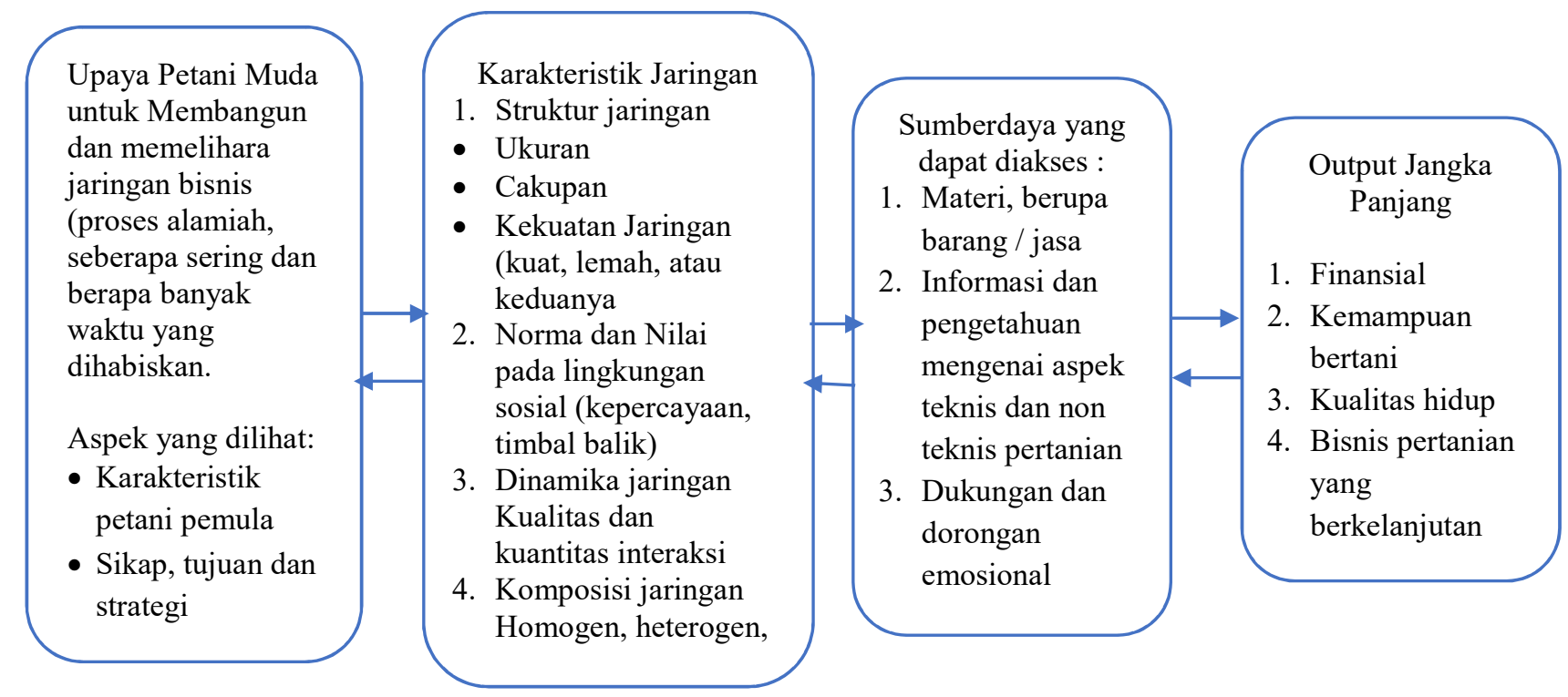

\section{Gambar 1. Jaringan Bisnis Petani Pemula ( Kerangka dan Indikator Penelitian)}

Proses wawancara dilakukan secara mendalam, diperkuat dengan observasi di lapangan, sehingga peneliti dapat memahami perilaku petani pemula dalam membangun jaringan, bagaimana mereka memperoleh bantuan dari pihak lain untuk mendapatkan sumberdaya yang dibutuhkan. Pada saat mereka menyebutkan aktor yang membantu mereka, maka responden diminta untuk menjelaskan secara spesifik sumberdaya yang disediakan dan bagaimana kekuatan hubungan sosial dengan aktor tersebut, serta menjelaskan alasan hubungan itu dibentuk atau dimulai.

\section{HASIL DAN PEMBAHASAN}

Secara umum, penelitian ini dirangkum menjadi tiga bagian seperti yang terdapat dalam Gambar 1, yaitu terdiri atas perilaku jaringan, struktur jaringan dan hasil jaringan. Pada pembahasan akan diperlihatkan perbandingan antara petani dengan latar 
belakang pertanian dan non pertanian. Petani pemula yang berasal dari kedua latar belakang yang berbeda ini memiliki kesepakatan yang sama bahwa jaringan dan dukungan sosial adalah sesuatu yang penting dalam bisnis yang mereka jalankan. Responden yang merupakan petani pemula dalam usahatani cabe mengungkapkan bahwa dia menghabiskan waktu dengan beberapa petani yang telah lebih dulu berkecimpung dalam usahatani cabe (kenalan petani cabe). Dalam proses interaksi, terjadi transfer knowledge dari petani lama kepada petani pemula tersebut. Apabila dilihat dari latar belakang petani pemula yang berasal dari keluarga petani, proses ini terjadi karena mereka telah saling mengenal lama, sehingga proses interaksi dapat berjalan dengan lebih mudah, dan proses transfer knowledge berjalan dengan lebih baik.

Responden selanjutnya menjelaskan bahwa ayahnya adalah petani yang disegani di lingkungan tersebut, sehingga mudah saja bagi dirinya untuk menyewa tanah dari tetangga di lingkungan sekitarnya, karena mereka segan pada ayah dari responden ini. Responden yang tidak memiliki latar belakang pertanian, tidak lahir di lingkungan pertanian, membutuhkan waktu bertahun-tahun untuk menemukan kenalan atau orang yang memang dapat dipercaya dan mungkin mau membantu mereka. Petani pemula dengan latar belakang pertanian umumnya cukup aktif dalam kegiatan-kegiatan yang berlangsung di desa nya, mereka terus berupaya untuk membangun jaringan lokal. Namun, umumnya mereka belum membangun jejaring yang lebih jauh cakupan nya, mereka sejauh ini masih berinteraksi dengan orang-orang yang dekat dengan mereka, berada di sekitar lingkungan tempat tinggal nya. Beberapa petani pemula pada kelompok ini bersedia menghadiri pertemuan antar petani apabila diadakan di lingkungan nya sendiri, umumnya mereka keberatan apabila kegiatan tersebut dilakukan jauh dari lingkungan mereka. Dari 15 responden petani pemula dengan latar belakang pertanian, hanya terdapat 2 responden yang bersedia menghadiri kegiatan-kegiatan yang terkait dengan penguatan bisnis pertanian jauh dari lingkungan mereka, sedangkan sisanya masih belum bersedia untuk melakukan hal tersebut.

Petani pemula dengan latar belakang non pertanian umumnya lebih terbuka, mereka bersedia untuk meluangkan waktu khusus untuk 
mengunjungi sentra-sentra pertanian di Jawa Barat (Kabupaten Bandung, Kabupaten Garut dan Kabupaten Cianjur). Mereka datang untuk mempelajari aspek teknis pertanian, mencoba untuk bekerjasama dengan tokoh masyarakat atau pihak desa sehingga mereka dapat berkenalan dengan petani-petani berpengalaman yang berada di sentra-sentra pertanian tersebut. Dilihat dari sisi sosial, petani dengan latar belakang non pertanian menilai bahwa mereka belum dapat menembus ikatan sosial yang telah terbentuk di lingkungan pertanian perdesaan. Hubungan dengan tetangga memang tetap berjalan dengan baik (ikatan lemah), namun ketika akan mulai melakukan aktivitas bisnis yang memerlukan tingkat kepercayaan yang lebih besar, maka hal tersebut masih dirasakan sulit untuk dilakukan, atau memerlukan waktu lama untuk sampai ke fase tersebut. Petani pemula non pertanian umumnya berhubungan dengan orang-orang yang dekat dengan mereka secara hubungan emosional, bukan karena kedekatan tempat tinggal. Petani yang berasal dari keluarga petani memiliki hubungan kuat dengan tempat tinggalnya, sedangkan petani yang berasal dari non pertanian, mereka lebih realistis, tidak terikat terhadap tempat tinggalnya. Mereka berpikir apabila tidak berhasil dalam usahatani, maka mereka akan pergi ke tempat lain yang lebih menjanjikan. Perbedaan antar petani dengan latar belakang yang berbeda terkait dengan proses membangun jaringan dapat dilihat pada Tabel 1.

\section{Struktur dan Komposisi Jaringan}

\section{Bisnis Pertanian}

Ikatan yang terjalin diantara ke -30 responden terdiri atas ikatan kuat dan lemah, terdapat ikatan kompleks dan tidak ada yang benar-benar homogen, dimana dalam prosesnya melibatkan banyak aktor di dalamnya. Perbedaan nya adalah terletak pada derajat ikatan. Ikatan yang kuat didominasi oleh petani yang memiliki wilayah geografis yang sama (teman sekolah, teman kecil, saudara, dll), memiliki ikatan kuat terhadap tempat tinggal nya. Ikatan lemah terdapat pada petani non pertanian, dimana mereka tidak memiliki waktu yang cukup untuk membangun ikatan yang kuat. Mereka berinteraksi dengan lingkungan nya, mendapat informasi dan pengetahuan tentang bisnis pertanian yang sedang mereka kerjakan, namun hanya sebatas itu, tidak ada hal lain yang dapat mereka peroleh (misalnya: informasi pasar dan lainnya). 
Jaringan petani non pertanian sangat beragam, mereka membangun jejaring bisnis praktis, meskipun dengan ikatan yang lemah, namun yang utama mereka dapat memperoleh support sumberdaya yang mereka butuhkan untuk bisnis nya. Jaringan petani berlatar belakang pertanian cukup beragam dan kompleks. Jaringan petani yang berasal dari lingkungan pertanian terbentuk secara lebih kompleks ; tetangga atau teman dekat mungkin membantu memberikan modal usaha, memberi pengetahuan praktis pertanian atau mendukung secara moril ketika petani pemula mengalami kegagalan usaha.
Ikatan yang multikompleks dapat terjalin dari ikatan sosial yang kuat seperti ini. Petani non pertanian umumnya belum mengalami ini, mereka tidak memiliki ikatan yang multikompleks, karena mereka masih dalam tahap menjalin hubungan dengan ikatan yang lemah. Sesekali mungkin mereka bisa mendapatkan sumberdaya yang kompleks dari ikatan tersebut, seperti sumberdaya material dan informasi teknis pertanian, namun sulit bagi mereka mendapatkan dukungan moril yang kuat dari lingkungan sekitarnya.

Tabel 1. Perbedaan Petani Berlatar Belakang Pertanian dan Non Pertanian

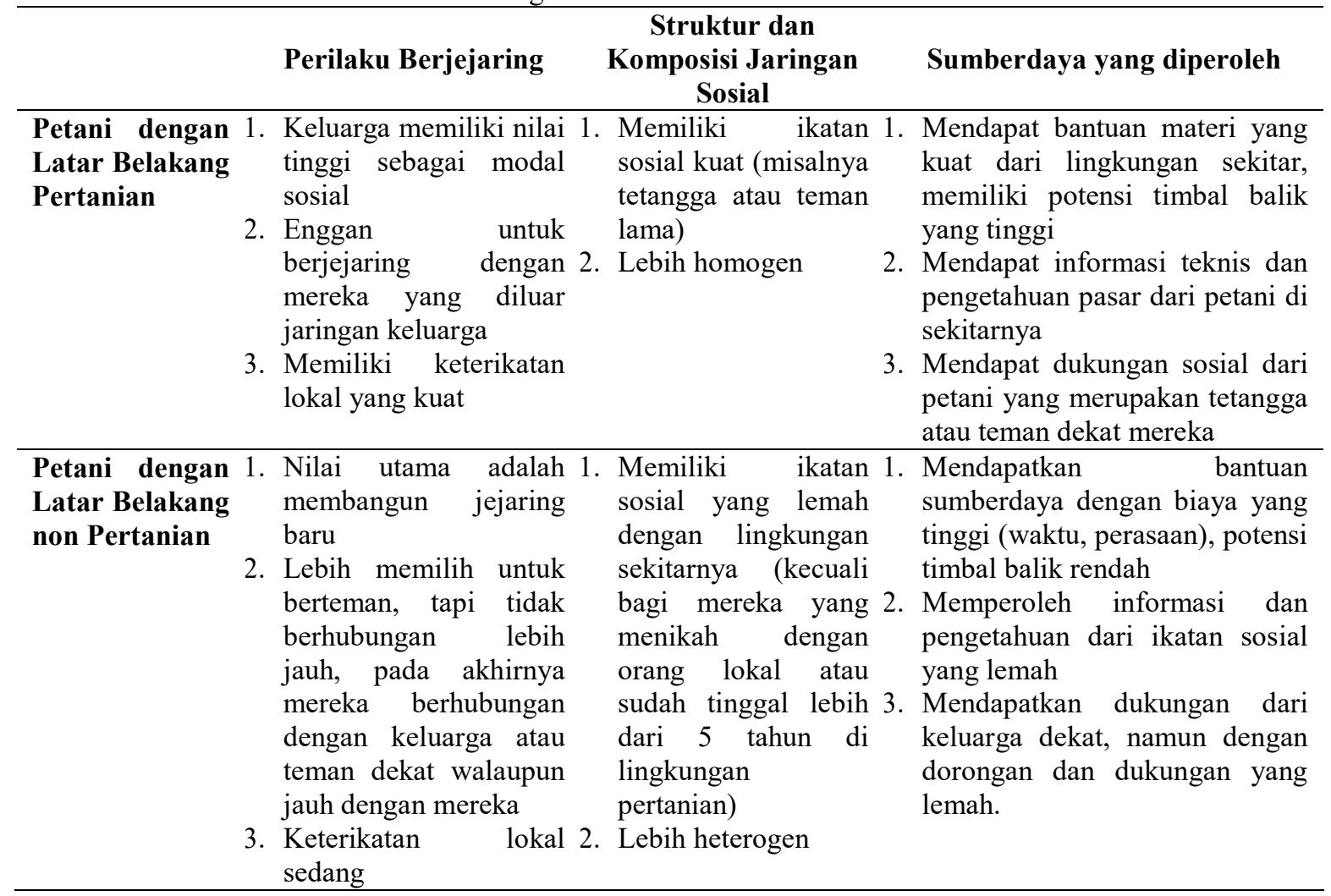


Sumberdaya yang Dapat Diakses dari

\section{Hasil Berjejaring}

Fokus pembahasan pada bagian ini adalah untuk melihat sumberdaya apa yang dapat diperoleh oleh petani pemula, terkait dengan upaya mereka dalam membangun jaringan bisnis. Petani asal pertanian mendapatkan kemudahan dalam sewa lahan, bibit, sarana produksi pertanian dan informasi teknis/pasar. Mereka memperoleh akses terhadap sumberdaya melalui ikatan keluarga yang homogen dan kuat, ditambah dengan ikatan terhadap kelembagaan yang ada di wilayah mereka, sehingga mereka mendapatkan hibah, bantuan ataupun pinjaman modal. Petani pemula non pertanian bekerja melalui ikatan yang lemah dalam mengakses sumberdaya yang dibutuhkan. Mereka seringkali menggunakan tabungan pribadi, atau menjual tanahnya untuk membiayai usahatani mereka pada tahap awal. Lingkungan sosial sepertinya belum siap untuk memberikan akses penuh terhadap petani non pertanian ini, seakan-akan mereka masih membutuhkan waktu untuk memberikan kepercayaannya kepada mereka.

Pada beberapa kasus, petani pemula non pertanian merasa tidak nyaman atau belum terbiasa dengan norma "timbal balik", yaitu lingkungan membantu mereka, namun lingkungan juga seringkali meminta bantuan lain kepada mereka. Setelah terbiasa umumnya mereka dapat melakukan hal ini, karena di Jawa Barat, perilaku saling tolongmenolong atau saling "timbal balik" dalam bantu - membantu adalah sesuatu yang biasa dilakukan dan telah menjadi norma sosial dalam kehidupan orang sunda secara umum.

Petani pemula pertanian banyak mendapatkan informasi dan pengetahuan praktis pertanian yang berasal dari kearifan lokal yang terdapat dalam lingkungan sekitarnya. Mereka umumnya mendapatkan hal tersebut dari keluarga, tetangga, petani tua di lingkungannya dan lainnya. Petani pemula non pertanian telah mengembangkan ikatan praktis yang efektif dengan masyarakat di sekitar mereka. Salah satu responden melakukan interaksi dengan tetangganya, melakukan komunikasi mengenai bisnis sayuran di lingkungan mereka. Seiring dengan berjalannya waktu, ikatan yang lemah ini telah memungkinkan terjadinya transfer knowledge yang kompleks dari lingkungan kepada petani pemula tersebut, meskipun dalam prosesnya terdapat biaya yang harus dibayarkan untuk mendapatkan semua itu. Poin 
utama yang harus diperhatikan dalam proses ini bagi petani pemula non pertanian terkait dengan biaya, waktu dan energi yang harus dicurahkan agar mereka dapat mengakses sumberdaya dalam lingkungan baru mereka.

Petani pemula non pertanian yang terdapat di sentra agribisnis Jawa Barat akhirnya mendapatkan akses sumberdaya, meskipun terdapat pengorbanan yang tidak sedikit di dalamnya. Beberapa petani responden mengatakan bahwa mereka telah mendapatkan sumberdaya melalui proses perjuangan yang panjang. Pada awal membangun bisnis, orang-orang di sekitar banyak yang mengatakan bahwa usahatani yang akan dijalankan tidak akan memberikan keuntungan, atau beberapa mengatakan bahwa kondisi keamanan di daerahnya kurang aman, sehingga kurang kondusif untuk menjalankan usaha disitu. Tentu ini adalah bentuk kekhawatiran mereka bahwa usahanya akan mendapat persaingan yang lebih banyak, apalagi berasal dari orang yang tidak mereka kenal sebelumnya. Seiring dengan perjalanan waktu, petani pemula dapat membuktikan bahwa kehadiran mereka justru memberikan manfaat bagi orangorang di sekitar mereka, dan perlahan mereka akan memberikan dukungan positif bagi petani pemula untuk mengembangkan usahatani nya. Sumberdaya akan mengalir kepada petani pemula pertanian melalui ikatan sosial yang kuat dengan keluarga/orang-orang terdekat di lingkungan mereka, sedangkan petani pemula non pertanian berusaha lebih keras untuk menemukan cara dalam mendapatkan dorongan dan dukungan yang dibangun dari ikatan yang lemah.

\section{KESIMPULAN DAN SARAN}

\section{Kesimpulan}

Penelitian ini mencoba untuk mengeksplorasi peranan yang dimainkan oleh jaringan sosiak dalam akses sumberdaya bagi petani baru, baik mereka yang berasal dari lingkungan pertanian maupun non pertanian di Jawa Barat. Jaringan sosial ini dianalisis dalam hal struktur dan komposisi jaringan, dan juga perilaku petani dalam berjejaring. Hasil penelitian menunjukkan bahwa ikatan kuat dan lemah memberikan kontribusinya masing-masing bagi petani pemula untuk mengakses sumberdaya. Petani pemula yang bukan berasal dari lingkungan pertanian berjuang lebih keras untuk membangun jejaring bisnis, memberikan pengorbanan yang lebih 
besar dalam mengakses sumberdaya yang mereka butuhkan. Petani pemula non pertanian mampu mengakses sumberdaya material yang biasanya didapatkan dari ikatan sosial yang kuat. Ternyata dengan usaha dan pengorbanan yang keras, mereka mampu mendapatkan sumberdaya dari ikatan sosial yang lemah.

Implikasi praktis dari penelitian ini adalah pentingnya menemukan cara untuk dapat memfasilitasi petani pemula non pertanian agar mereka dapat membangun jejaring dengan masyarakat lokal, sehingga mereka dapat dengan cepat membentuk ikatan yang kuat dalam komunitas perdesaan. Apakah hal ini mungkin untuk dilakukan? Peneliti melihat bahwa hal ini sangat mungkin dilakukan di wilayah Jawa Barat, dimana orang Sunda itu memiliki karakter "Someah ka tamu",, namun tentu pendatang pun harus terlebih dahulu memahami karakter orang sunda dengan baik sehingga tidak menimbulkan kesalahpahaman antara satu dengan yang lainnya. Pertanian adalah sektor yang senantiasa mengalami perubahan yang cepat, sehingga kedua kelompok petani pemula ini harus mampu bergerak dengan cepat, melintasi "batas" untuk mengakses

\footnotetext{
${ }^{1}$ Sopan dan dapat menerima tamu dengan baik
}

sumberdaya dengan cara yang inovatif dari berbagai sumber yang ada.

\section{Saran}

Penelitian selanjutnya mungkin dapat dilakukan dengan lebih fokus pada mekanisme ikatan sosial dalam jaringan bisnis petani. Melihat fenomena jaringan antar petani hortikultura di Jawa Barat. Dalam hal ini bisa dilihat kesesuaian antara studi mengenai jaringan sosial dan juga studi mengenai konteks budaya, khususnya di Jawa Barat. Pertanyaan selanjutnya yang menurut peneliti penting adalah melihat fenomena petani yang tidak memiliki latar belakang pertanian masuk ke dalam dunia pertanian. Apabila jaringan sosial dan kemampuan berjejaring ini menjadi kunci pengembangan pertanian yang dinamis dan modern, maka penting melakukan penelitian yang bertujuan untuk mendapatkan wawasan yang lebih komprehensif tentang sikap dan perilaku petani generasi baru terhadap jaringan usaha mereka. Hal ini penting dilakukan agar pertanian kita dapat terus berkembang dan beradaptasi dengan baik terhadap berbagai perubahan yang ada saat ini. 


\section{DAFTAR PUSTAKA}

Acheampong, G., Narteh, B., \& Rand, J. (2017). Network ties and survival: a study of small commercial poultry farms in Ghana. The International Journal of Entrepreneurship and Innovation, 18(1), 14-24.

Baker, W. (2014). Making pipes, using pipes: how tie initiation, reciprocity, positive emotions, and reputation create new organizational social capital. In Contemporary perspectives on organizational social networks. Emerald Group Publishing Limited.

Beggs, J. J., Haines, V. A., \& Hurlbert, J. S. (1996). Revisiting the RuralUrban Contrast: Personal Networks in Nonmetropolitan and Metropolitan Settings 1. Rural Sociology, 61(2), 306-325.

Bourdieu, P. (1986). The forms of capital. Handbook of theory and research for the sociology of education. JG Richardson. New York, Greenwood, 241(258), 19.

Brüderl, J., \& Preisendörfer, P. (1998). Network support and the success of newly founded business. Small Business Economics, 10(3), 213225.

Casson, M., \& Giusta, M. Della. (2007). Entrepreneurship and social capital: Analysing the impact of social networks on entrepreneurial activity from a rational action perspective. International Small Business Journal, 25(3), 220-244.

Coleman, J. S. (1988). Social capital in the creation of human capital. American Journal of Sociology, 94, S95-S120.

Dasgupta, P., \& Serageldin, I. (2000). Social capital: a multifaceted perspective. World Bank Publications.

Dinda, S. (2014). Inclusive growth through creation of human and social capital. International Journal of Social Economics.

Flora, C. B., McIsaac, G., Gasteyer, S., \& Kroma, M. (2001). FarmCommunity Entrepreneurial Partnerships in the Midwest. In Interactions between agroecosystems and rural communities (pp. 131-146). CRC Press.

Granovetter, M. (2005). The impact of social structure on economic outcomes. Journal of Economic Perspectives, 19(1), 33-50.

Greve, A., \& Salaff, J. W. (2003). Social networks and entrepreneurship. Entrepreneurship Theory and Practice, 28(1), 1-22.

Grootaert, C. (1999). Social capital, household welfare and poverty in Indonesia. World Bank Publications.

Hassanein, N. (1999). Changing the way America farms: Knowledge and community in the sustainable agriculture movement (Vol. 12). U of Nebraska Press.

Heaney, C. A., \& Israel, B. A. (2008). Social networks and social support. Health Behavior and Health Education: Theory, Research, and Practice, 4, 189-210.

Jenssen, J. I. (2001). Social networks, resources and entrepreneurship. The International Journal of Entrepreneurship and Innovation, 2(2), 103-109.

Jenssen, J. I., \& Koenig, H. F. (2002). The effect of social networks on resource access and business startups. European Planning Studies, 10(8), 1039-1046.

Kuntarič, A., Schwarz, E. J., Breitenecker, R. J., \& Wdowiak, M. A. (2012). The effects of social capital on the performance of newly founded businesses in Slovenia. International Journal of 
Entrepreneurship and Small Business 9, 15(1), 100-115.

Mailfert, K. (2007). New farmers and networks: how beginning farmers build social connections in France. Tijdschrift Voor Economische En Sociale Geografie, 98(1), 21-31.

McElwee, G, \& Robson, A. (2005). Diversifying the farm: opportunities and barriers. Journal of Rural Research and Policy, (4), 84-96.

McElwee, Gerard, \& Bosworth, G. (2010). Exploring the strategic skills of farmers across a typology of farm diversification approaches. Journal of Farm Management, 13(12), 819-838. https://doi.org/10.1109/ISSCC.200 9.4977519

Meixner, O., Ameseder, C., Haas, R., Canavari, M., Fritz, M., \& Hofstede, G. J. (2009). Importance of trust building elements in business-to-business agri-food chains. Journal of Farm Management, 13(9), 655-668.

Mudiarta, K. G. (2017). Jaringan Sosial (Networks) dalam Pengembangan Sistem dan Usaha Agribisnis: Perspektif Teori dan Dinamika Studi Kapital Sosial. Forum penelitian Agro Ekonomi, 27(1), 1. https://doi.org/10.21082/fae.v27n1. 2009.1-12

Murdoch, J. (2000). Networks - a new paradigm of rural development? Journal of Rural Studies, 16(4), 407-419.

Nee, V. (2005). The new institutionalisms in economics and sociology. The Handbook of Economic Sociology, 2, 49-74.

Novitasari, R. (2019). Peran dan Kinerja Sektor Pertanian dalam Perekonomian Jawa Barat.

Palmioli, L., Grando, S., Di Iacovo, F., Fastelli, L., Galli, F., Prosperi, P.,
... Brunori, G. (2020). Small farms' strategies between selfprovision and socio-economic integration: Effects on food system capacity to provide food and nutrition security. Local Environment, 25(1), 43-56.

Phillipson, J., Gorton, M., Raley, M., \& Moxey, A. (2004). Treating Farms as Firms? the Evolution of Farm Business Support from Productionist to Entrepreneurial Models. Environment and Planning C: Government and Policy, 22(1), 31-54.

https://doi.org/10.1068/c0238

Pyysiäinen, J., Anderson, A., McElwee, G., \& Vesala, K. (2006). Developing the entrepreneurial skills of farmers: some myths explored. International Journal of Entrepreneurial Behavior \& Research, 12(1), 21-39. https://doi.org/10.1108/135525506 10644463

Semrau, T., \& Werner, A. (2014). How exactly do network relationships pay off? The effects of network size and relationship quality on access to start-up resources. Entrepreneurship Theory and Practice, 38(3), 501-525.

Spigel, B. (2016). Bourdieu, culture, and the economic geography of practice: entrepreneurial mentorship in Ottawa and Waterloo, Canada. Journal of Economic Geography, lbw019. https://doi.org/10.1093/jeg/lbw019

White, B. (2012). Agriculture and the Generation Problem: Rural Youth, Employment and the Future of Farming. IDS Bulletin, 43(6), 9-19. https://doi.org/10.1111/j.17595436.2012.00375.x

Witt, P. (2004). Entrepreneurs' networks and the success of start-ups. Entrepreneurship \& Regional 
Development, 16(5), 391-412.

Wood, B., Larasati, R. S., \& Laksana, B. (2020). Rural Indonesian Youths'

Conceptions of Success.
Zimmer, C. (1986). Entrepreneurship through social networks. The Art and Science of Entrepreneurship. Ballinger, Cambridge, MA, 3, 23. 